\title{
SINTASAN DAN PERKEMBANGAN COCOON LINTAH LAUT (Zeylanicobdella arugamensis) PADA SUHU YANG BERBEDA
}

\author{
Ketut Mahardika ${ }^{a^{*}}$, Indah Mastuti ${ }^{\mathrm{a}}$, dan Zafran ${ }^{\mathrm{a}}$ \\ ${ }^{a}$ Balai Besar Riset Budidaya Laut dan Penyuluhan Perikanan, Desa Penyabangan, Kec. Gerokgak, kab. \\ Buleleng, Bali, Indonesia \\ * Koresponden penulis: kmahardika@yahoo.com
}

\begin{abstract}
Abstrak
Lintah laut (Zeylanicobdella arugamensis) merupakan ektoparasit yang sering menginfeksi ikan kerapu di keramba jaring apung. Penelitian ini bertujuan untuk mengetahui pengaruh suhu inkubasi terhadap sintasan lintah laut dan perkembangan cocoon (telur). Lintah laut dikoleksi dari ikan kerapu hibrida cantang (panjang total 5-7 cm) dan menempatkannya pada cawan petri. Sebanyak 108-232 ekor lintah laut hidup ditempatkan dalam setiap satu cawan petri yang telah diisi air laut dengan salinitas 32 ppt (total 16 cawan petri). Masing-masing 4 cawan petri di inkubasi dalam inkubator suhu 37,30 dan $25^{\circ} \mathrm{C}\left( \pm 1{ }^{\circ} \mathrm{C}\right)$, dan suhu ruang $20-23{ }^{\circ} \mathrm{C}$. Lintah laut dan cocoon yang dihasilkan diinkubasi selama 18 hari. Hasil pengamatan menunjukkan bahwa lintah laut dapat bertahan hidup selama: 3 hari pada suhu $36-37{ }^{\circ} \mathrm{C}$, 10 hari pada suhu 29-30 ${ }^{\circ} \mathrm{C}, 13$ hari pada suhu $20-23{ }^{\circ} \mathrm{C}$, dan 15 hari pada suhu $25-26{ }^{\circ} \mathrm{C}$. Akan tetapi, jumlah lintah laut yang bertahan hidup menurun seiring pertambahan waktu inkubasi. Rata-rata jumlah cocoon yang berkembang pada suhu inkubasi $25-26{ }^{\circ} \mathrm{C}$ lebih tinggi $(\mathrm{P}<0,05)$ dibandingkan dengan suhu inkubasi lainnya. Cocoon yang menetas menjadi larva lintah laut menunjukkan jumlah tertinggi $(38,71 \pm 7,90 \%$ b) pada suhu inkubasi $25-26{ }^{\circ} \mathrm{C}$ dan berbeda nyata dibandingkan dengan jumlah cocoon yang menetas pada suhu inkubasi 29-30 ${ }^{\circ} \mathrm{C}\left(3,86 \pm 2,95 \%\right.$ a). Sedangkan cocoon pada suhu $36-37{ }^{\circ} \mathrm{C}$ dan $20-23{ }^{\circ} \mathrm{C}$ tidak ada yang menetas $(0$ a). Hasil tersebut menunjukkan bahwa lintah laut dan cocoon mampu bertahan hidup lebih lama dan menetas lebih banyak pada suhu $25-26^{\circ} \mathrm{C}$.
\end{abstract}

Kata kunci: cocoon, lintah laut, suhu inkubasi.

\begin{abstract}
Leeches (Zeylanicobdella arugamensis) are commonly infecting groupers in floating net cages. This study aims to determine the effect of incubation temperature on the survival of sea leeches and the development of its cocoon (eggs). Sea leeches were collected from the hybrid grouper (Epinephelus fuscoguttatus $\times$ E. lanceolatus, with total length of 5-7 cm) and placed on a petri dish. a 108 to 232 live marine leeches were placed in each petri dish filled with seawater with salinity of $32 \mathrm{ppt}$ (total of 16 petri dishes). Each of the 4 petri dishes was incubated in an incubator at temperatures 37,30 and $25{ }^{\circ} \mathrm{C}$ (range $\pm 1{ }^{\circ} \mathrm{C}$ ), and room temperature of $20-23{ }^{\circ} \mathrm{C}$. Leeches and its cocoons were incubated for 18 days. The result showed that sea leeches can survive for: 3 days at $36-37{ }^{\circ} \mathrm{C}, 10$ days at $29-30{ }^{\circ} \mathrm{C}, 13$ days at $20-23{ }^{\circ} \mathrm{C}$, and 15 days at $25-26$ ${ }^{\circ} \mathrm{C}$. However, the number of surviving sea leeches decreases with incubation time. The average number of cocoons that developed at an incubation temperature of $25-26^{\circ} \mathrm{C}$ was higher $(\mathrm{P}<0.05)$ compared to other incubation temperatures. Cocoons that hatch into sea leech larvae show the highest number $(38.71 \pm 7.90 \%$ b) at an incubation temperature of $25-26^{\circ} \mathrm{C}$ and was significantly different than the number of cocoons that hatch at an incubation temperature of $29-30{ }^{\circ} \mathrm{C}\left(3.86 \pm 2.95 \%\right.$ a). While cocoons at a temperature of $36-37^{\circ}$ $\mathrm{C}$ and $20-23{ }^{\circ} \mathrm{C}$ were not hatches $(0$ a). These results indicate that sea leeches and its cocoon were able to survive longer and hatch more at $25-26^{\circ} \mathrm{C}$.
\end{abstract}

Keywords: cocoon, sea leech, incubation temperature.

\section{PENDAHULUAN}

\begin{tabular}{lcr}
\multicolumn{1}{c}{ Lintah } & (hirudinea, & Zeylanicobdella \\
arugamensis) & dilaporkan & lebih banyak \\
ditemukan pada ikan & kerapu yang
\end{tabular}

dibudidayakan di keramba jaring apung (KJA). Lintah merupakan salah satu parasit utama yang selalu ada dan menginfeksi ikan di lingkungan budidaya di perairan terbuka [1]. Infeksi lintah pada budidaya ikan kerapu 
lebih sering terjadi di akhir sampai pertengahan tahun (November sampai Juli) dengan prevalensi berkisar antara $10-100 \%$. Prevalensi tertinggi terjadi di bulan MaretJuni [2].

Lintah laut dan cocoon-nya dapat hidup dan menetas pada media pemeliharaan air laut sampai air payau (5-30 ppt). Namun persentase kelulushidupan lintah dan telurnya sampai hari ke-11 pada salinitas tersebut bervariasi (2,6-56\%) [3]. Lintah laut dilaporkan juga dapat bertahan hidup selama 45 menit pada salinitas tinggi yaitu 90 sampai 100 ppt. Daya hidup lintah laut bertambah hingga 120 menit pada salinitas yang lebih rendah 40-60 ppt. Cocoon lintah tidak dapat berkembang dan menetas setelah dipelihara dalam air laut salinitas 40-100 ppt selama 11 hari. Cocoon tersebut dapat berkembang dan menetas jika terendam dalam air salinitas 40 ppt selama 1-3 hari [4].

Lintah laut dilaporkan dapat hidup dan berkembangbiak dengan baik pada suhu antara 25 sampai $35{ }^{\circ} \mathrm{C}$, akan tetapi tidak dapat berkembangbiak pada suhu $40{ }^{\circ} \mathrm{C}$ [5]. Seperti dilaporkan sebelumnya, prevalensi infeksi lintah laut teringgi terjadi pada bulan Maret sampai Juni dimana bulan-bulan tersebut merupakan musim peralihan dari musim hujan ke musim kemarau. Tren suhu di perairan Bali Utara pada tahun 2018 dilaporkan mulai meningkat di pertengahan bulan Januari $\left(28 \pm 0,84^{\circ} \mathrm{C}\right)$ hingga bulan April $\left(30 \pm 1,0^{\circ} \mathrm{C}\right)$, dan mengalami penurunan hingga nilai terendah di bulan Agustus (28,22 $\left.\pm 0,36^{\circ} \mathrm{C}\right)$. Tren kenaikan suhu dimulai pada akhir bulan Agustus hingga bulan Desember 2018. Suhu (sebagai variabel tetap) merupakan salah satu faktor dalam memengaruhi penguraian kandungan organik yang masuk ke perairan [6]. Suhu merupakan salah satu faktor penentu dari siklus hidup lintah laut. Oleh karena itu perlu diketahui suhu optimal untuk perkembangbiakan lintah laut sehingga dapat menjadi rujukan para pembudidaya ikan laut terutama di KJA untuk melakukan tindakan pencegahannya. Tujuan dari penelitian ini adalah untuk mengetahui pengaruh suhu inkubasi terhadap sintasan lintah laut dan perkembangan cocoon.

\section{BAHAN DAN METODE}

\section{Lintah}

Lintah laut (Zeylanicobdella arugamensis) lintah diisolasi dari ikan kerapu hibrida cantang (ㅇ Kerapu macan Epinephelus fuscoguttatus $\mathrm{X} \curvearrowright \mathrm{o}$ kerapu kertang E. lanceolatus) dengan panjang total sekitar 5-7 cm. Ikan-ikan tersebut dalam kondisi moribund dengan gejala berenang lemah dan diam di dasar bak. Tubuh ikan telah dipenuhi dengan lintah sehingga kondisinya kurus. Lintah diisolasi dari 10 ekor kerapu cantang yang dipeliharan di bak fiber (volume 500 L) di Laboratorium Patologi, Balai Besar Riset Budidaya Laut dan Penyuluhan Perikanan (BBRBLPP). Lintah diisolasi dengan cara mengurut tubuh ikan yang dipenuhi lintah dan ditampung ke dalam cawan petri dengan diameter $8 \mathrm{~mm}$ (total 16 cawan petri) yang telah diisi air laut langsung. Kemudian lintah dalam cawan petri dibilas beberapa kali dengan air laut langsung untuk menghilangkan lendir ikan yang ikut terbawa dalam cawan petri.

\section{Inkubasi lintah}

Lintah-lintah dalam cawan petri diinkubasi pada suhu ruangan laboratorium basah $\left(29-30{ }^{\circ} \mathrm{C}\right)$ selama 1 jam untuk memberikan waktu recovery lintah setelah proses isolasi dari ikan. Air pemeliharaan lintah diganti kembali untuk menghilangkan lintah-lintah yang lemah dan tidak menempel di cawan petri. Masing-masing 4 cawan petri diinkubasi pada inkubator yang telah diatur suhunya ke suhu 37,30 dan $25{ }^{\circ} \mathrm{C}\left( \pm 1{ }^{\circ} \mathrm{C}\right)$. Sedangkan 4 cawan petri lainnya diinkubasi pada suhu ruangan laboratorium parasitologi yang ber AC (suhu $20-23{ }^{\circ} \mathrm{C}$ ). Pada masingmasing suhu inkubasi ditempatkan pula botol kaca volume $500 \mathrm{~mL}$ yang diisi air laut langsung untuk menambahkan air pemeliharaan lintah dalam cawan petri yang menguap terutama di suhu tinggi (30 dan 37 $\left.{ }^{\circ} \mathrm{C}\right)$. Lintah laut dan cocoonnya diinkubasi selama 18 hari. Suhu air pemeliharaan lintah diukur setiap hari pada pagi hari sekitar jam 09.00-10.00 wita.

\section{Pengamatan lintah dan cocoon}

Pengamatan terhadap respon lintah dan cocoon-nya dilakukan secara makroskopis dan 
mikroskopis. Lintah yang hidup dan mati dihitung pada setiap perlakuan, demikian pula jumlah telur yang berkembang dan larva yang menetas selama 18 hari inkubasi. Hasil pengamatan di analisa Anova dan jika berbeda nyata $(\mathrm{p}<0,05)$ dilanjutkan dengan uji Duncan.

\section{HASIL DAN PEMBAHASAN}

Hasil pengamatan suhu dan salinitas air pemeliharaan lintah dalam cawan petri seperti tertera dalam Tabel 1.

Tabel 1. Suhu dan salinitas air pemeliharaan lintah dalam cawan petri selama inkubasi dalam inkubator dan ruangan laboratorium.

\begin{tabular}{ccc}
\hline $\begin{array}{c}\text { Suhu } \\
\text { inkubator/ruangan }\end{array}$ & Suhu $\left({ }^{\circ} \mathrm{C}\right)$ & $\begin{array}{c}\text { Salinitas } \\
(\mathrm{ppt})\end{array}$ \\
\hline 37 & $36-37$ & $32-33$ \\
\hline 30 & $29-30$ & $31-32$ \\
\hline 25 & $25-26$ & $31-32$ \\
\hline 20 & $20-23$ & $31-32$ \\
\hline
\end{tabular}

Pada Tabel 1 terlihat suhu air pemeliharaan lintah dalam cawan petri pada masing-masing suhu inkubator terjadi rentang $1{ }^{\circ} \mathrm{C}$. Sedangkan suhu ruangan ber AC yang diatur ke suhu $20{ }^{\circ} \mathrm{C}$ mengalami peningkatan sampai $2{ }^{\circ} \mathrm{C}$. Perlakuan suhu $20^{\circ} \mathrm{C}$ dilakukan pada ruangan ber AC karena keterbatasan inkubator di laboratorium Patologi BBRBLPP. Peningkatan atau penurunan suhu inkubator kemungkinan disebabkan adanya buka-tutup pintu inkubator ketika pengamatan, maupun suhu ruangan tempat inkubator tersebut berada atau disimpan. Demikian halnya suhu ruangan laboratorium terjadi peningkatan lebih banyak dipengaruhi oleh suhu lingkungan. Cuaca pada saat dilakukan penelitian adalah panas (kemarau).

Salinitas air pemeliharaan lintah pada suhu inkubator $36-37^{\circ} \mathrm{C}$ terjadi sedikit peningkatan dibandingkan dengan suhu inkubasi lainnya karena adanya penguapan air. Penguapan air lebih banyak terjadi pada suhu $36-37{ }^{\circ} \mathrm{C}$ sehingga penambahan air pemeliharaan lintah dilakukan hampir setiap hari. Penguapan air pemeliharaan lintah hampir tidak ditemukan pada suhu inkubasi $25-26{ }^{\circ} \mathrm{C}$ jika dibandingkan dengan suhu inkubasi $20-23{ }^{\circ} \mathrm{C}$ yang lebih banyak dipengaruhi oleh ruangan ber-AC.

Hasil pengamatan daya tahan lintah untuk bertahan hidup pada suhu inkubasi 36$37{ }^{\circ} \mathrm{C}$ menunjukkan lintah (rata-rata jumlah lintah: $163,5 \pm 4,43$ ekor) hanya dapat bertahan hidup sampai 3 hari pasca inkubasi. Lintah-lintah tersebut terlihat banyak mengambang mulai hari pertama pasca inkubasi dan beberapa lainnya terlihat mati dengan tubuh melingkar dan mengkerut. Kematian mencapai $6,42 \%$ pada hari pertama dan meningkat pada hari kedua $(43,57 \%)$ dan mencapai $100 \%$ pada hari ketiga pasca inkubasi (Gambar 1). Kematian lintah mungkin disebabkan oleh suhu inkubasi yang tinggi.

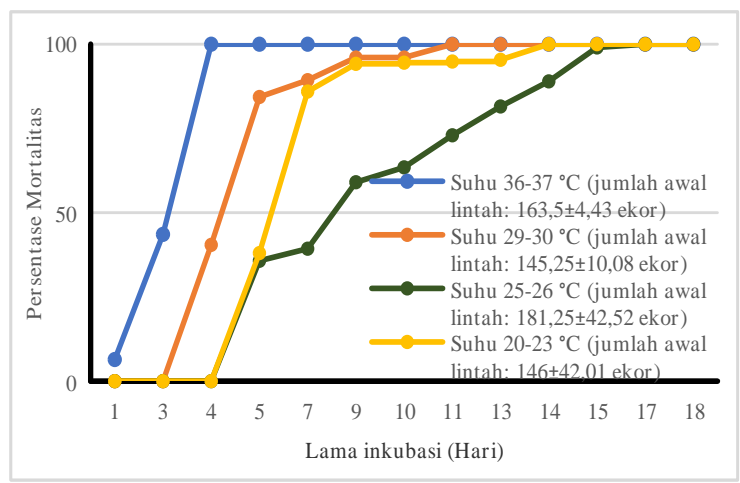

Gambar 1. Mortalitas lintah pada suhu inkubasi berbeda selama 18 hari pemeliharaan.

Lintah yang diinkubasi pada suhu 29-30 ${ }^{\circ} \mathrm{C}$ (Gambar 1) menunjukkan kematian mulai hari ke-4 pasca inkubasi, lebih cepat satu hari dibandingkan dengan suhu inkubasi $25-26{ }^{\circ} \mathrm{C}$ dan 20-23 ${ }^{\circ} \mathrm{C}$. kematian lintah semakin meningkat seiring dengan pertambahan waktu inkubasi. Kematian lintah pada suhu inkubasi $29-30{ }^{\circ} \mathrm{C}$ mencapai $100 \%$ terjadi pada hari ke11 lebih cepat dibandingkan dengan lintah yang diinkubasi pada suhu $20-23{ }^{\circ} \mathrm{C}$ yang dapat bertahan hidup sampai hari ke-13 (100\% mortalitas pada hari ke-14). Sedangkan lintah yang diinkubasi pada suhu $25-26{ }^{\circ} \mathrm{C}$ dapat bertahan hidup lebih lama sampai 15 hari pasca inkubasi walaupun jumlahnya sangat sedikit $(0,97 \%)$. Hasil penelitian ini sejalan dengan hasil penelitian sebelumnya, yang melaporkan bahwa lintah dewasa dan juvenil dapat hidup hingga 11-16 hari pada suhu $25{ }^{\circ} \mathrm{C}$, lebih lama dibandingkan dengan lintah yang diinkubasi pada suhu $27-30{ }^{\circ} \mathrm{C}$ 
yaitu hingga 5-13 hari dan suhu $35-40{ }^{\circ} \mathrm{C}$ hingga 10 jam-5 hari [5]. Kemampuan lintah dewasa untuk bertahan hidup tanpa inang hingga dua minggu pada suhu $29-31^{\circ} \mathrm{C}$ dalam sistem air mengalir maupun air diam [3]. Lintah-lintah yang hidup pada semua perlakuan suhu terlihat lemah dengan tubuh yang kurus. Lintah tersebut terlihat mengambang pada permukaan air atau berdiam lemah dan tidak mampu menempel pada dasar atau tepian cawan petri sebelum mati.

Tabel 2. Jumlah dan perkembangan cocoon yang dihasilkan oleh lintah pada suhu berbeda selama 18 hari pengamatan.

\begin{tabular}{|c|c|c|c|c|c|}
\hline \multirow{2}{*}{ Perlakuan } & \multirow{2}{*}{ Jumlan coccon } & \multicolumn{2}{|c|}{ Coccon yang berkembang } & \multicolumn{2}{|c|}{ Cocconyangmenetas } \\
\hline & & Jumlah & $(\%)$ & Jumlah & $(\%)$ \\
\hline 0 & 139 & $6,96 \pm 1,80$ & 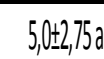 & & 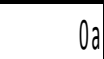 \\
\hline Uhu 29. & 144,7 & $40,04 \pm 16,10$ & $27,66+8,072$ & $5,59+2,25$ & $0,00 I_{2}$ \\
\hline${ }^{\circ} \mathrm{C}$ & $104,0500,01$ & $80,40 \pm 38,66$ & $77,3177,266$ & $40,26+19,36$ & $1 \pm 7,906$ \\
\hline Suhu 20223 & $199,25+55,90$ & $28,32413,28$ & $23,7577,502$ & & - \\
\hline
\end{tabular}

Lintah yang diinkubasi pada semua perlakuan suhu $\left(20-37 \quad{ }^{\circ} \mathrm{C}\right)$ dapat menghasilkan cocoon/telur (Tabel 2). Ratarata jumlah cocoon bervariasi dari setiap perlakuan yang disebabkan oleh perbedaan jumlah lintah dewasa, jumlah lintah dewasa yang bertelur, jumlah cocoon yang dihasilkan dari setiap individu lintah dewasa dan faktor fisik lintah serta faktor lingkungan. Satu ekor lintah dewasa mampu menghasilkan cocoon hingga 63 butir. Lintah dapat menghasilkan cocoon 2-3 jam setelah ditempatkan dalam cawan petri [3]. Hal tersebut menunujukkan bahwa lintah yang digunakan dalam penelitian ini diberi perlakuan suhu setalah 1 jam isolasi, sehingga lintah tersebut belum menghasilkan cocoon atau jumlah cocoon yang dihasilkan sangat sedikit. Lintah dewasa menghasilkan cocoon lebih banyak setelah perlakuan diinkubasi. Lintah dewasa mampu menghasilkan Cocoon hingga 3 hari setelah meepaskan diri dari inangnya [7].

Tabel 2 juga menunjukkan bahwa walaupun banyak cocoon yang dihasilkan (104,0 $\pm 50,01-144,75 \pm 58,19$ butir), namun tidak semuanya dapat berkembang $(6,96 \pm 1,80-80,40 \pm 38,66$ butir). Persentase perkembangan cocoon yang diinkubasi pada suhu $25-26{ }^{\circ} \mathrm{C}$ lebih tinggi $(77,31 \%)$ dan berbeda nyata $(\mathrm{p}<0,05)$ dibandingkan dengan perlakuan suhu lainnya. Persentase perkembangan cocoon terendah terlihat pada perlakuan suhu inkubasi $36-37{ }^{\circ} \mathrm{C}(5,0 \%)$. cocoon tidak berkembang menjadi menjadi embrio dalam 7 hingga 10 hari disebabkan karena cocoon yang tidak dibuahi atau kondisi yang tidak menguntungkan untuk proses perkembangbiakan embrio. Namun, faktorfaktor yang mempengaruhi kondisi yang tidak menguntungkan tersebut tidak dapat ditentukan [5].

Hasil pengamatan perkembangan cocoon menunjukkan bahwa tidak semua cocoon yang telah berkembang dapat menetas menjadi larva $(0-40,26 \pm 19,36$ butir yang menetas). Persentase dari cocoon yang menetas pada suhu inkubasi $25-26{ }^{\circ} \mathrm{C}$ lebih tinggi $(38,71 \%)$ dan berbeda nyata $(\mathrm{p}<0,05)$ dibandingkan dengan perlakuan suhu 29-30 ${ }^{\circ} \mathrm{C}(3,86 \%)$ dan dua perlakuan lainnya (36-37 dan $20-23{ }^{\circ} \mathrm{C}: 0 \%$ ). Hasil penelitian ini sejalan dengan hasil yang dilaporkan sebelumnya yaitu cocoon dapat menetas pada rentang suhu 25 sampai $35{ }^{\circ} \mathrm{C}$ [5]. Lebih jauh dilaporkan bahwa persentase daya tetas cocoon tertinggi terjadi pada suhu inkubasi $27{ }^{\circ} \mathrm{C}(54,3 \pm 2,0 \%)$, diikuti dengan suhu inkubasi $25{ }^{\circ} \mathrm{C}$ $(32,3 \pm 0,6 \%), 30{ }^{\circ} \mathrm{C}(14,3 \pm 1,5 \%)$ dan $35{ }^{\circ} \mathrm{C}$ $(13,3 \pm 0,6 \%)$. Cocoon tidak dapat menetas pada suhu inkubasi $40{ }^{\circ} \mathrm{C}$. Sedangkan hasil penelitian kami sebelumnya menunjukkan bahwa daya tetas cocoon yang dihasilkan per individu lintah dewasa yang diinkubasi pada suhu 29-31 ${ }^{\circ} \mathrm{C}$ berkisar antara 2,70 hingga $100 \%$ [3].

Pada suhu inkubasi $36-37{ }^{\circ} \mathrm{C}$ dan $20-23$ ${ }^{\circ} \mathrm{C}$, cocoon mengalami perkembangbiakan hingga tahap gastrula sampai awal pembentukan embrio (4-6 hari pasca inkubasi). Cocoon tersebut selanjutnya tidak mengalami perkembangan lagi menuju stadium embrio atau tidak menetas menjadi larva lintah (Gambar 2A dan D). Sedangkan cocoon yang tidak berkembang pada semua perlakuan terlihat hanya sampai tahap awal perkembangan yaitu stadium blastula (Gambar 2 C) dan sebagian cocoon yang tidak berkembang tidak mempunyai inti atau kuning telur (Gambar 2 B). 


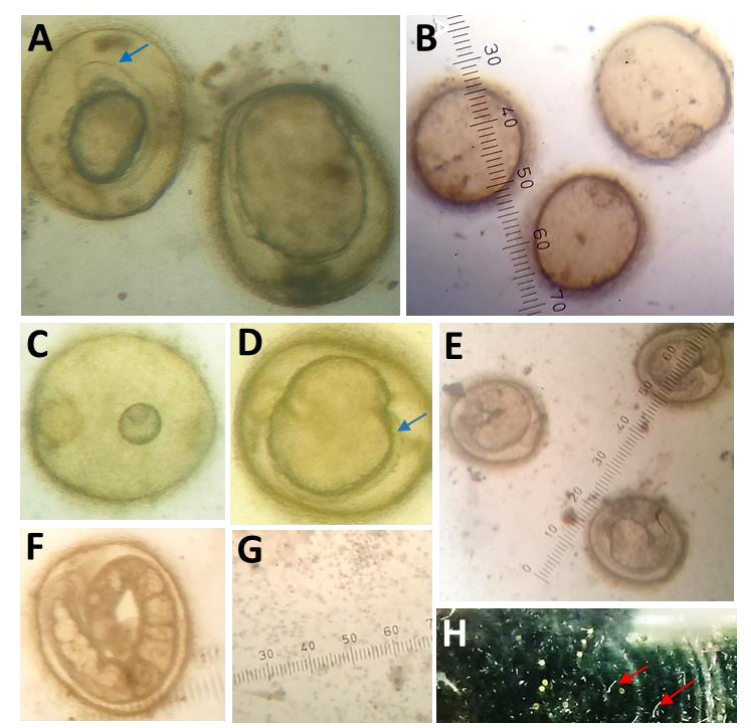

Gambar 2. Perkembangan cocoon. A). Cocoon yang diinkubasi pada suhu $37^{\circ} \mathrm{C}$ yang berkembang sampai hari ke-6 pasca inkubasi, dimana embrio mulai terbentuk (tanda panah), B).

Cocoon pada suhu inkubasi $37^{\circ} \mathrm{C}$ yang tidak berkembang sampai hari ke-10, C). Cocoon pada suhu inkubasi $20^{\circ} \mathrm{C}$ yang tidak berkembang (6 hari pasca inkubasi), D). Cocoon yang mengalami perkembangan embrio selama 5 hari inkubasi pada suhu $20^{\circ} \mathrm{C}$, dimana terjadi awal pembentukan embrio (tanda panah), E). Cocoon yang diinkubasi sampai hari ke-7 pada suhu $30{ }^{\circ} \mathrm{C}$ telah mengalami perkembangan embrio menjadi bentuk larva lintah,

F). Perkembangan cocoon yang telah mencapai bentuk larva lintah pada hari ke-10 pasca inkubasi pada suhu $\left.25^{\circ} \mathrm{C}, \mathrm{G}\right)$. Protozoa yang ditemukan pada pemeliharaan lintah dan cocoon pada suhu 25-26 dan $29-30{ }^{\circ} \mathrm{C}, \mathrm{H}$ ). Larva lintah yang telah menetas (tanda panah) terlihat mengambang dan mati setelah 2 hari menetas.

Cocoon yang tidak berkembang kemungkinan disebabkan karena cocoon tidak dibuahi atau nutrisi yang kurang memadai, atau mungkin faktor lainnya yang belum diketahui secara pasti. Sedangkan terhentinya perkembangan cocoon stadium gastrula atau awal perkembangan embrio menjadi bentuk embrio dan larva lintah kemungkinan disebabkan karena energi cocoon tersebut tidak mencukupi untuk melanjutkan proses perkembangbiakan selanjutnya. Energi yang dimiliki cocoon kemungkinan besar habis terserap untuk menjaga stabilitas kondisi cocoon terhadap suhu panas $\left(36-37{ }^{\circ} \mathrm{C}\right)$ atau dingin $\left(20-23{ }^{\circ} \mathrm{C}\right)$.
Cocoon yang berkembang dan tidak menetas pada perlakuan inkubasi suhu 25-26 ${ }^{\circ} \mathrm{C}$ dan 29-30 ${ }^{\circ} \mathrm{C}$ lebih banyak disebabkan oleh protozoa (Gambar 2G) yang banyak mengerubuti cocoon dan memakan lintah yang mati. Protozoa tersebut berkembangbiak dengan cepat seiring dengan banyaknya lintah yang mati dan cocoon yang tidak berkembang.

Cocoon yang berkembang menjadi stadia embrio (Gambar 2E dan F) dan menetas menjadi larva lintah (Gambar 2H). Perkembangan cocoon sampai menetas memerlukan waktu 10-13 hari pasca inkubasi 25-26 ${ }^{\circ} \mathrm{C}$ dan $29-30{ }^{\circ} \mathrm{C}$. Siklus hidup cocoon menjadi larva lintah dilaporkan memerlukan waktu 8-10 hari pada suhu 29-31 ${ }^{\circ} \mathrm{C}$ dengan salinitas 34-35 ppt [3]. perkembangan cocoon sampai menetas menjadi larva lintah memerlukan waktu yang lebih lama (12 hari) pada suhu $24-25{ }^{\circ} \mathrm{C}$ dengan salinitas $34 \mathrm{ppt}$ [8]. Perkembangan cocoon menjadi larva lintah dilaporkan lebih cepat (7 hari) pada suhu $27{ }^{\circ} \mathrm{C}$ dengan salinitas $28 \mathrm{ppt}$ [7]. Selain suhu, salinitas dilaporkan juga berpengaruh terhadap kehidupan lintah laut dan cocoon yang dihasilkannya. Lintah laut dapat bertahan hidup pada salinitas 5 sampai $30 \mathrm{ppt}$ selama 11 hari, walaupun jumlahnya menurun $(3,9-73,1 \%)$. Demikian pula dengan cocoon, dapat berkembang dan menetas pada hari ke 9-11 (2,6-47,4\%) setelah diinkubasi di salinitas 5-30 ppt [9]. Persentase daya tetas cocoon lebih tinggi pada salinitas $30 \mathrm{ppt}(32,5$ $2,8 \%$ ) dibandingkan dengan salinitas $20 \mathrm{ppt}$ $(18,04,3 \%)$ dan 10 ppt (12,1 1,4\%). Lintah dewasa dan lintah kecil dapat hidup hingga kisaran rata-rata 4-7 hari di salinitas mulai dari 10 hingga $40 \mathrm{ppt}$ [5]. Lintah dapat bertahan hidup selama 45 menit dengan salinitas 90-100 ppt, dan hingga 120 menit pada salinitas 40-60 ppt. Demikian pula dengan cocoon tidak dapat berkembang dan menetas setelah dipelihara dalam air laut salinitas 40-100 ppt selama 11 hari. Akan tetapi, cocoon masih dapat berkembang dan menetas setelah direndam dalam air laut salinitas 40 ppt selama 1-3 hari [4].

Fluktuasi salinitas antara 1 dan $3 \mathrm{ppt}$ umumnya terlihat di air tropis selama musim hujan [5]. Lebih lanjut dilaporkan bahwa jika rata-rata persentase cocoon yang menetas 
mencapai $60 \%$ di lingkungan tropis alami dengan salinitas berkisar antara 26 hingga 30 ppt dan pada suhu air 26 hingga $30^{\circ} \mathrm{C}$, maka lebih banyak generasi lintah laut dapat bertahan hidup dan itu dapat menyebabkan potensi risiko yang lebih tinggi terhadap budidaya ikan. Potensi infeksi lintah yang lebih tinggi juga dilaporkan pada budidaya ikan kerapu dan kakap putih di KJA di Teluk pegametan, Bali-Utara, dimana isidensi kejadian infeksi lintah lebih banyak ditemukan ketika musim peralihan antara musim hujan ke musim kemarau, begitu juga sebaliknya $[1,2]$.

Lintah laut dilaporkan dapat dibunuh menggunakan $50 \mathrm{ppm}$ formalin selama 1 jam [10]. Akan tetapi dalam perkembangannya, lintah laut tersebut baru dapat dimatikan dengan perendaman formalin dan hidrogen peroksida pada dosis $100-200 \mathrm{mg} / \mathrm{L}$ dalam air tawar selama 60 menit [11].

\section{KESIMPULAN}

Dari hasil penelitian tersebut dapat disimpulkan bahwa lintah laut dapat bertahan hidup lebih lama pada suhu inkubasi $20-30{ }^{\circ} \mathrm{C}$ (10-15 hari) dibandingkan dengan suhu inkubasi $36-37{ }^{\circ} \mathrm{C}$ (3 hari) walaupun jumlah lintah laut yang bertahan hidup menurun seiring pertambahan waktu inkubasi. Rata-rata jumlah cocoon yang berkembang dan menetas menjadi larva lintah pada suhu inkubasi 25-26 ${ }^{\circ} \mathrm{C}$ lebih tinggi dan berbeda nyata dibandingkan dengan suhu inkubasi lainnya.

\section{UCAPAN TERIMAKASIH}

Penulis mengucapkan terimakasih kepada teknisi litkayasa Laboratorium Patologi BBRBLPP yang telah membantu dalam penelitian ini.

\section{DAFTAR PUSATAKA}

[1] Zafran, D. Roza, \& K. Mahardika. "Prevalensi ektoparasit pada ikan budidaya di keramba jaring apung di Teluk Kaping, Buleleng, Bali". Prosiding Ikatan Sarjana Oseanologi Indonesia (ISOI), hal. 100-108, 2019.
[2] K. Mahardika, I. Mastuti, D. Roza, D. Syahidah, W.W. Astuti, S. Ismi, \& Zafran. "Pemantauan insidensi penyakit pada ikan kerapu dan kakap di hatchery dan keramba jaring apung di bali utara”. Jurnal Riset Akuakultur, 2020 (inpress).

[3] K. Mahardika, I. Mastuti, Sudewi, \& Zafran, "Identification and life cycle of marine leech isolated from cultured hybrid grouper in the Northern Bali water of Indonesia". Indonesian Aquaculture Journal, 13 (1), 41-49, 2018

[4] K. Mahardika, I. Mastuti, \& Zafran. "Respon lintah laut (Zeylanicobdella arugamensis) terhadap salinitas tinggi secara in vitro dan in vivo". Fisheries, Fakultas Teknik dan Ilmu Kelautan, Universitas Hang Tuah, Surabaya, 2020 (inpress).

[5] B.C. Kua, F.C. Choong, \&Y.Y. Leaw, "Effect of salinity and temperature on marine leech, Zeylanicobdella arugamensis (De Silva) under laboratory conditions. Journal of Fish Diseases, 37, 201-207, 2013.

[6] A. Nasukha, R. Septory, Sudewi, A. Setiadi, \& K. Mahardika. "Sebaran temporal parameter kimia dan fisika perairan pantai yang berdekatan dengan beberapa lokasi budidaya laut di Bali Utara". Jurnal Riset Akuakultur, 14(1), $17-27,2019$.

[7]. C. Kua, M.A. Azmi, \& N.K.A. Hamid, "Life cycle of the marine leech (Zeylanicobdella arugamensis) isolated from sea bass (Lates calcarifer) under laboratory conditions". Aquaculture, 302, 153-157, 2010.

[8] Murwantoko, S.L.C. Negoro, A. Isnansetyo, \& Zafran, "Life cycle of marine leech (Zeylanicobdela arugamensis) from cultured cantik hybrid grouper (Ephinephelus sp.) and their susceptibility against chemicals". 
Aquacultura Indonesia, 18(2), 72-76, 2017.

[9] K. Mahardika, I. Mastuti, \& Zafran. "Respon lintah laut (Zeylanicobdella arugamensis) terhadap salinitas berbeda secara laboratorium". Journal of Fisheries and Marine Research, 2(3), 208-214, 2018.

[10] E.R.C. Cruz-Lacierda, J.D. Toledo, \& E.M. Burreson, "Marine leech (Zeylanicobdella arugamensis) infestation in cultured orange-spotted grouper, Epinephelus coioides". Aquaculture, 185 (3-4), 191-196, 2000.

[11] K. Mahardika, I. Mastuti, A. Muzaki, \& Zafran. "Efektivitas beberapa bahan kimia terhadap cocoon dan lintah laut hirudinea (Zeylanicobdella arugamensis)". Jurnal Riset Akuakultur, 14(1), 29-38, 2019. 